\title{
Determinants of IPOs Initial Return: Extreme Analysis of Indian Market
}

\author{
Rohit Bansal, Ashu Khanna \\ Institute of Technology, Roorkee Uttrakhand, India \\ Email: rohitbansaliitr@gmail.com, ashukfpt@iitr.ernet.in
}

Received July $2^{\text {nd }}, 2012$; revised August $17^{\text {th }}, 2012$; accepted September $14^{\text {th }}, 2012$

\begin{abstract}
This paper attempts to design and test empirical models, which integrate theoretical, institutional, and other factors, which interact to explain ownership structure. Ex-ante information at the level of underpricing succeeds the Indian stock market crunch. The study is based on IPO that listed at Bombay stock exchange given that April 2000 to December 2011. Multiple linear regressions are used to distinguish the relationship between various independent variables with the dependent variable, i.e. level of underpricing. The outcomes of multiple regressions reveal that, firm's age, IPO years, book building pricing mechanism, ownership structure, issue size, \& market capitalization explained $44 \%$ of the variation in issuer underpricing, Durbin Watson's value subsisted 1.58, which indicates that, there is a positive sequential relationship between variables. Number of share offered, issue size, market capitalization, subscription offer timing, book building mechanism and IPO years 2006, 2009 \& 2011 are constructed to have important effect on the level of underpricing after the Indian market crisis. Nevertheless, firm's age, IPOs year 2008, private issuing firms, non institutional promoters, Indian promoters and non institutional non promoters contain no significant difference in the level of underpricing after-market crisis.
\end{abstract}

Keywords: IPOs; Post Market Crisis; Ownership Structure; Share Holding Pattern; BSE; Underpricing; Firm Specific Factors; Market Related Variables

\section{Introduction}

Undoubtedly, initial public offerings (IPOs) have generated an enormous amount of public interest and are one of the most researched areas in finance. Common empiricisms have shown that IPOs are subject to three well documented anomalies, namely, the short-term underpricing of IPOs, the hot issue market phenomenon and the long-run performance of IPOs. With regard to short-term underpricing, issuers offer shares to investors at prices considerably below the subsequently revealed market value. The underpricing of IPOs is anomalous in the sense that it appears to contradict the efficient market's hypothesis. In particular, one would expect the underpricing of IPOs to disappear over time as the devastating majority of investors will recognize the implied profit opportunities and make good use of them. However, the underpricing of IPOs seems to be persistent in most markets. Furthermore, it would be difficult to rationally justify the behavior of living owners to sell shares to outsiders at discounted prices. The fact that these anomalies exist in numerous developed and developing markets makes them even more difficult to explain.

There are a number of theoretical explanations and models underpinning this IPO underpricing. The popular justifications for this observed phenomenon rest upon the possible existence of information asymmetries, mainly in the form of ex ante uncertainties about share prices. Also, according to (Welch, 1989), (Grinblatt \& Hwang, 1989) and other similar studies, there exists a signaling mechanism where firms send signals to the market by underpricing their IPOs. Moreover, there are other possible explanations such as underwriter reputation theories, investor sentiment theories and prospect theories to explain the degree of underpricing in the IPO market.

\section{Role of BSE in Book Building Process}

BSE offers the book building services through the book building software that runs on the BSE private network. This system is one of the largest electronic book building networks anywhere spanning over 350 Indian cities through over 7000 trader work stations via leased lines, VSATs and campus LANS. The software is operated through book-runners of the issue and by the syndicate member brokers. Through this book, the syndicate member brokers on behalf of themselves or their clients' place orders. Bids are placed electronically through syndicate members, and the information is collected on line real-time until the bid date ends. In order to maintain transparency, the software gives visual graphs displaying price v/s quantity on the terminals.

\section{Theories and Models of Underpricing}

Therefore, a number of competing theoretical models have been developed to explain the initial underpricing of stocks. The main theories found in the IPO literature are the winner's curse hypothesis, bookbuilding theories, and the principal-agent hypothesis, signaling theories, the law-suit avoidance hypothesis, the ownership and control hypothesis and the investor sentiment theory. One of the most important models of underpricing is the one developed by (Rock, 1986) based on the winner's curse hypothesis. Rock distinguishes between informed and uninformed investors. If the issues are underpriced, IPOs will be oversubscribed by informed investors, resulting in a limited number of shares being available to uninformed investors. If the issues are overpriced, IPOs will be sold exclusively to uninformed investors who will earn negative initial returns. Thus, 
uninformed investors will be winning the entire issue but at an unfavorable price, creating a situation termed the winner's curse. In order to keep uninformed investors in the IPO market, securities are offered at a discount from their expected after market prices. Thus, according to the winner's curse theory, IPO underpricing should decrease if the information asymmetry between informed and uninformed investors is reduced.

Empirical studies have found evidence that the underpricing for IPOs of financial institutions is related to proxies for asymmetric information. Signaling (Allen \& Faulhaber, 1989) asymmetric information (Ibbotson, 1975) Offer size (Megginson \& Weiss, 1991) age of the firm (Muscarella \& Vetsuypens, 1989) market capitalization, (McDonald \& Fisher, 1972), (Baker \& Wurgler, 2007), Pricing mechanism (Bansal \& Khanna, 2012) determinants of IPO underpricing at BSE (Bansal \& Khanna, 2012).

(Leite, 2007), generalized the informational assumptions of the (Rock, 1986) to address empirical evidence and conjectures that the standard model based on informed and uninformed investors is unable to address. They showed that high (low) market returns induce the issuer to price the issue more conservatively (aggressively) to create a negative relation between the public signal and the quality of the marginal investor, and in turn a positive relation between market returns and underpricing.

(Dolvin \& Jordon, 2008), addressed the question of whether or not periods of high underpricing adversely affect pre-existing shareholders. They found that high levels of underpricing are associated with increased share retention, which effectively offsets much of the potential cost. Overall, the percentage of shareholder wealth lost is stable over time, unlike underpricing itself. Also many factors known to be related to underpricing are not significant determinants of the cost of going public to pre-existing owners.

(Kumar, 2010) examines the efficiency of IPO issuing mechanisms using a sample of Indian IPOs that tapped the primary market during 2003-2007 by taking into thoughtfulness the total costs the issuers have to face i.e., including both direct as well as indirect costs. He finds that from a total cost point of view the issuers fare neither better nor worse using either book building or the fixed price offers. Their results also indicated that the issue expenses associated with book building are more than those associated with fixed price offers after controlling for issue size and firm specific characteristics.

(Bansal \& Khanna, 2012), analyzes that whatever there is any significant difference in the magnitude of level of underpricing of IPOs that priced through the book build with those are priced through the fixed price option. They found that the magnitude of underpricing is concerned; the book-build and fixed price option gave different results. They found significant difference in level of magnitude of underpricing in IPOs that priced during the book build with those that are priced through the fixed price option.

\section{Objectives}

1) To measure the IPOs initial performance on first trading day.

2) Does ownership structure of Indian stock market affect the level of the underpricing?

3) Do Ex-ante uncertainty variables impact the degree of underpricing in Bombay stock market?

\section{Research Methodology}

\section{Sample and Data Collection Methods}

The sample used in this study consists of all Indian firms which went public on the official market of the Stock Exchange of Bombay for the period April 2000 until 2011. Presume the limited number of firms, we have included those that were delisted during the sample period. The prospectus is used to collect data prior to listing. These include the offer price, issue details, dates and amounts, the sponsoring stockbroker, the auditor, and financial information from balance sheets and income statements. Notwithstanding, for some firms, there is no prospectus and in such cases the annual reports before the year of listing are used to collect ex-ante information. Furthermore, information on the issue details of such firms is manually collected from the Registrar of Companies, which keeps files for all private and public companies in Mauritius. Furthermore, the SEBI Handbook, which provides a 5-year summary of income statements and balance sheets for all listed companies, is also consulted. Moreover, the SEBI Fact book, an annual publication issued by the SEBI to disseminate information to investors, is used to collect information on the main market indicators as well as information pertaining to rights issues and bonus issues by listed companies. In addition, regular price histories were collected for each sample firm through the period 1999-2011. In particular, daily share price data for all sample firms from the listing date up to three years subsequent to listing are obtained from the (SEBI's) own quotes as well as from different stock broking companies.

\section{Measure of Underpricing}

Consistent with the standard methodology, underpricing is calculated as the percentage changing from the offer price to the closing price in the secondary market.

Equation 1 Log underpricing $=\ln (\mathrm{P} 1-\mathrm{P} 0 / \mathrm{P} 0) \cdot 100$

where P0 $=$ Offer price of the IPOs offered to public, P1= First day closing price of IPOs listed at stock exchange.

$\log$ Underpricing $=\ln (\mathrm{P} 1-\mathrm{P} 0 / \mathrm{P} 0) \cdot 100$ is used to determine the level of underpricing and to make standard practice and to avoid hetroscadisticity. We have market adjusted returns on securities (MAARO).

Firstly, we calculate the return on i security, where we used $\mathrm{Ri}=(\mathrm{P} 1-\mathrm{P} 0) / \mathrm{P} 0$ in which, $\mathrm{Ri}=$ return on $\mathrm{i}$ security, $\mathrm{P} 1=$ Price of $i$ security on first listing day, $\mathrm{P} 0=$ offer price of $\mathrm{i}$ security.

$$
\text { Equation } 2 \mathrm{Ri}=(\mathrm{P} 1-\mathrm{P} 0) / \mathrm{P} 0
$$

Secondly, we calculate index return on corresponding days, where we used $\mathrm{Mi}=(\mathrm{Ii}-\mathrm{I} 0) / \mathrm{I} 0$ in which, $\mathrm{Mi}=$ market return on ith day, $\mathrm{Ii}=$ closing index at listing day, $\mathrm{I} 0=$ closing index at offer day.

$$
\text { Equation } 3 \mathrm{Mi}=(\mathrm{Ii}-\mathrm{I} 0) / \mathrm{I} 0
$$

If markets are highly volatile such that there is a major change in the price of most stocks during the IPO period, then initial returns should be market adjusted. To compute the first day market adjusted return, the return of the market index is initially calculated as is the closing value of the market index on the issue date corresponding to the offering by firm $\mathrm{i}$ and $\mathrm{Mi}$ 
is the value of the market index corresponding to the offering price of the firm i. The market adjusted return abnormal return for each IPO on the first trading day is therefore computed as: MAARO. Finally, we calculate market adjusted return on security, where we take Ri from Equation (2) and Mi from Equation (3).

$$
\text { Equation } 4 \text { Maaro }=\{100 \cdot[(1+\mathrm{Ri}) / 1+\mathrm{Mi})-1]\}
$$

However, the measure in Equation (4) rests upon the assumption that the systematic risk of the IPOs under consideration is the same as that of the index. Indeed, it is highly unlikely that the betas of the IPOs average to unity, as a number of studies (e.g., Ibbotson, 1975; Affleck-Graves et al., 1996) have shown that the average betas of the newly listed firms are systematically higher than one. As such, the MAARO may be upwardly biased in the sense that a higher initial performance of the IPO relative to the market could be observed.

Underpricing is used as dependent variable in this multiple regression model.

Null Hypothesis: H0: There is no significant difference between several independent variables with the level of underpricing.

\section{Measure of Year of IPOs (Dummy Variables)}

For the measures of IPOs year, we used different years (2008), (2009), (2010) and (2011) as a dummy variable. Dummy variable is used to indicate the years of IPOs issued during IPOs underpricing. The presence of more IPOs underpricing (In terms of percentage) years showed with value equal to 1 and 0 otherwise.

H1: There is a positive significant relationship between the years of IPOs i.e., 2011 and degree of underpricing.

\section{Measures of Ownership Structure}

The ownership structure of a company comprises of a distribution of the size of investor shareholdings. Applying a single measure in the form of a proportion is to be sufficient to delineate distributions with varying shapes. Numbers of shares are held by promoters and non promoters. We have also taken the total percentage of their shares holding in the ownership structure. Afterwards we have converted it into the natural logarithms to make standardized value and to remove the hetroscadisticity.

$\mathrm{H} 2$ : There is a positive significant relationship between Indian promoters and degree of underpricing.

H3: There is a positive relationship between intuitional non promoters and the level of underpricing.

H4: There is a positive link between non intuitional non promoters and level of underpricing.

\section{Measure of Number of Share Offered}

Number of share offered is measured by the total quantity of shares that issuing firm has offered to their investors. Afterwards we have transformed it into the natural logarithms to make standardized value and to remove the hetroscadisticity.

H5: There is a positive relationship between number of share offered and degree of underpricing.

\section{Measure of Firm's Age}

Firm age is measured in years as the difference between the year of IPO and the year of incorporation of the firm.
H6: There is no significant relationship between firm's age and degree of underpricing.

\section{Measure of Issue size (Total Amount to Be Raised)}

The issue size is measured as the total number of shares offered multiplied by the offer price. However, the total amount of IPOs (in Crores) rose by the company. Again, the natural logarithm of this value is used as a standard practice and to remove hetroscadisticity.

$\mathrm{H} 7$ : There is a negative significant connection between issue size and level of underpricing.

\section{Measure of Market Capitalization}

The market capitalization is measured as the total number of shares multiplied by the market price per share. Again, the natural logarithm of this value is used as a standard practice and to remove hetroscadisticity.

H8: There is no significant relationship between market capitalizations and less underpricing.

\section{Measure of Subscription}

The subscription is measured as the total number of shares acquired by several investors on the day of offering. Again, the natural logarithm of this value is used as a standard practice and to remove hetroscadisticity.

H9: There is a positive relationship between subscription and level of underpricing.

\section{Measure of Pricing Mechanism (Dummy Variable)}

In Indian primary market, there are two pricing techniques that are used to determine the nature of IPOs i.e. book build pricing mechanism and fixed price option. For the pricing mechanism again a dummy variable is used to indicate the presence of book build in IPO underpricing. The presence of book build pricing mechanism in IPOs is shown with value equal to 1 and 0 otherwise.

H10: There is a negative link between book build pricing mechanism and level of underpricing.

\section{Measure of Private Issuing Firms (Dummy Variable)}

Past data revealed that IPOs issuing company is in two types i.e. some are government companies and some are private companies. Therefore, to analyze the difference between IPOs underpricing and the nature of company types, we used measures of types of firms as a variable in our model. For the measures of the firm's types, again a dummy variable is used to indicate the presence of private firms in IPOs underpricing. The presence of private firms in IPOs is shown with value equal to 1 and 0 otherwise.

H11: There is a negative link between book build pricing mechanism and level of underpricing.

\section{Measure of Offer Timing (Difference between Offer Date of an IPOs \& First Day Listing Date of an IPOs)}

Sometime company decides the short period of their IPOs between offer date and the listing date on different stock exchange. Nevertheless, sometime they decided that offer timing is measured in days as the difference between the IPOs offer date, finalized by the issuing firm's first day listing of the IPOs at stock exchange.

H12: More offer timing leads to more level of underpricing. 


\section{The Multiple Regressions Model}

The impact of the independent variables namely, subscription rate, issue size, market capitalization, offer timing, firm's age, number of share offered, private firms (dummy), ownership structure, IPOs years (dummy) and pricing mechanism (dummy) by book build option on the dependent variable underpricing is modeled through multiple regression as:

\section{Estimation Equation}

Underpricing $(\log$ maaro $)=\alpha+\beta 11 \log ($ Indprm $)+\beta 2$ $\log ($ Issue size $)+\beta 3$ (Book build $)+\beta 4 \log$ (Market cap) $+\beta 5$ $\log ($ Pvt firms) $+\beta 6 \log$ (Instnonprm) $+\beta 7$ Log (Noninstnonpom $)+\beta 81 \log ($ Subsc $)+\beta 9 \log ($ Offer timing $)+$ $\beta 10 \log$ (Firm's age $)+\beta 11 \log$ (No of offered share) + $\beta 122001 y+\beta 132002 y+\beta 142003+\beta 152004+\beta 16$ $2005 y+\beta 172006 y+\beta 182007 y+\beta 192009 y+\beta 20$ $2010 \mathrm{y}+\beta 212011 \mathrm{y}+\mathrm{e}$

where, Log Maaro $=$ marked adjusted return of IPOs, $\beta=$ parameters, $\log ($ Indprm $)=$ Indian promoters, $\log ($ Issue size $)=$ Issue size, Book build = pricing mechanism book build (Dummy variable), Market cap $=$ Market capitalization, Log ( Pvt Firms $)=$ Private firms $($ Dummy variable $), \log ($ Inst non prm $)=$ Institutional non promoters, Log (Non inst non pom), Non institutional non promoters, Log $($ Subsc $)=$ Subscriptions, Log $($ Offer timing $)=$ Difference between IPOs offer date and IPOs first day listing date, Log (Firm's age) = Firm's age, Log (No of offered share) $=$ Number of shares offered to public, $\varepsilon=$ Constant.

\section{Data Collection and Analysis}

Table 1 reveals the details for initial public offerings that were listed at Bombay stock exchange (2000-2011). Total (550) IPOs were listed at Bombay stock exchange. However, (405)

Table 1.

IPOs at Bombay stock exchange from 2000-2011.

\begin{tabular}{cccccccc}
\hline Year & Total & BSE & BB & FPO & BB-Und BB-OverFPO-Und \\
\hline $\mathbf{2 0 0 0}$ & 118 & 67 & 11 & 56 & 6 & 5 & 30 \\
$\mathbf{2 0 0 1}$ & 16 & 10 & 2 & 8 & 0 & 2 & 2 \\
$\mathbf{2 0 0 2}$ & 5 & 5 & 1 & 4 & 0 & 1 & 4 \\
$\mathbf{2 0 0 3}$ & 14 & 11 & 4 & 7 & 3 & 1 & 5 \\
$\mathbf{2 0 0 4}$ & 28 & 25 & 17 & 8 & 9 & 8 & 6 \\
$\mathbf{2 0 0 5}$ & 70 & 67 & 48 & 19 & 26 & 21 & 14 \\
$\mathbf{2 0 0 6}$ & 90 & 89 & 68 & 21 & 36 & 32 & 14 \\
$\mathbf{2 0 0 7}$ & 106 & 105 & 91 & 14 & 58 & 32 & 7 \\
$\mathbf{2 0 0 8}$ & 38 & 38 & 33 & 5 & 16 & 17 & 2 \\
$\mathbf{2 0 0 9}$ & 21 & 21 & 21 & 0 & 14 & 7 & 0 \\
$\mathbf{2 0 1 0}$ & 73 & 73 & 71 & 2 & 47 & 24 & 2 \\
$\mathbf{2 0 1 1}$ & 40 & 39 & 38 & 1 & 19 & 19 & 0 \\
Total & 619 & 550 & 405 & 145 & 234 & 169 & 86 \\
\hline
\end{tabular}

IPOs were underpriced, out of which (234) IPOs were underpriced using book build pricing mechanism and (169) IPOs were underpricing using fixed price option. Table includes some abbreviations such as, BSE (Bombay stock exchange), BB (Book building pricing mechanism), FPO (Fixed price option), BB-Under (IPOs underpricing using book building), BB over (IPOs overpricing using book building), FPO under (Details of IPOs underpricing using fixed price option underpricing), FPO over (IPOs overpricing using fixed price option).

\section{Descriptive Statistics}

Table 2 indicates the descriptive results for all the variables that are used in our regression model i.e. Pricing mechanism (book building), different IPOs years, firm's age, offer size of IPOs, ownership structure, issue size and market capitalization of the firm's. Nevertheless, we used mean, median, standard deviation, skewness, kurtosis and Jarquebera test for normality. Results reveal the maximum mean value (6.46) \& (3.48) for market capitalization and issue size respectively and standard deviation (2.18) for market capitalization.

Figure 1 exhibits the mean and standard values for all the variables that are used in regression model i.e. Pricing mechanism (book building), different IPOs years, firm's age, offer size of IPOs, ownership structure, issue size and market capitalization of the firm's. However, we also draw a trend line for mean value.

\section{Multiple Regression Analysis}

Table 3 shows the result of multiple regression analysis, which includes the basic information below:

Dependent Variable: LOGMAARO;

Method: Least Squares;

Sample (adjusted): 1319;

Included observations: 319 after adjustments.

Table 2.

Descriptive statistics for all variables used in multiple regressions.

\begin{tabular}{ccccccc}
\hline Name & Mean & Media & $\begin{array}{c}\text { Std. } \\
\text { Dev. }\end{array}$ & Skew & Kurt & Jarque-Bera \\
\hline BB & 0.73 & 1 & 0.44 & -1 & 2.11 & 69.72 \\
A10 & 0.15 & 0 & 0.36 & 1.92 & 4.69 & 234.31 \\
A11 & 0.05 & 0 & 0.23 & 3.72 & 14.8 & 2603.84 \\
A8 & 0.05 & 0 & 0.23 & 3.84 & 15.7 & 2957.5 \\
Age & 2.56 & 2.5 & 0.97 & -0.29 & 3.73 & 11.73 \\
Offer & 0.26 & 0 & 0.94 & 3.4 & 13.1 & 1979.28 \\
Non ins & 1.1 & 0 & 1.44 & 0.2 & 2.97 & 2.19 \\
INDN & 2.43 & 3 & 1.87 & -2.1 & 9.29 & 761.84 \\
INDP & 3.83 & 4.19 & 1.35 & -4.84 & 34.77 & 14668.7 \\
ISSUESI & 4.48 & 4.44 & 1.73 & 0.1 & 3.44 & 3.21 \\
MKTC & 6.06 & 5.95 & 2.18 & -0.12 & 3.64 & 6.27 \\
MAARO & 3.02 & 3.31 & 1.48 & -0.46 & 2.76 & 12.06 \\
\hline
\end{tabular}




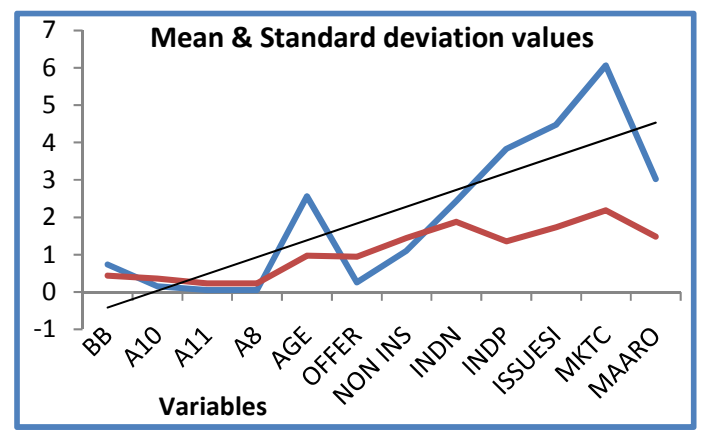

Figure 1.

Value for mean and standard deviations of all variables used in our regression model.

\section{Results \& Discussions}

Based on the multiple linear regression results (see Table 3), it was clear that the entire variables were regressed against the level of underpricing. There is a significant relationship between IPO years $(2006,2009 \& 2011)$ and the level of underpricing at $5 \%$ significance level ( $\mathrm{z}$-value $=-1.79,-1.92 \&$ $1.69)$. This examined that IPO year $(2006,2009)$ has an important negative effect on the level of underpricing. However, IPO year 2011 has a positive effect on the level of underpricing. Therefore, null hypothesis 1 is rejected in the case of the IPO year $(2006,2009 \& 2011)$. At the same time, null hypothesis 1 is accepted in the case of rest of the IPO years, which indicates that there is no significant link between IPO years and level of underpricing. It reveals that there is no relevant link between Indian promoters and degree of underpricing @ 5\% significance level $(\mathrm{z}=0.187)$. In addition, null hypothesis 2 is accepted. It examines no consequential association between institutional non promoters and level of underpricing @ 5\% significance level $(\mathrm{z}=0.541)$. There is no significant link between institutional non promoters and underpricing. Hence, null hypothesis 3 is accepted. There is no significant difference between non institutional non promoters with the degree of underpricing at $5 \%$ significant level $(\mathrm{z}=0.785)$. Nevertheless, null hypothesis 4 is accepted. It founded for significant relation of the number of share offered with a level of underpricing at $5 \%$ significance level $(z=1.99)$. It communicates the positive link between numbers of share offered with the level of underpricing. Consequently, null hypothesis 5 is rejected. There is no significant relationship between firm's age and level of underpricing at $5 \%$ significance level $(\mathrm{z}=-0.70)$. Accordingly, null hypothesis 6 is acknowledged.

There is a significant association of issue size at the level of underpricing at $5 \%$ significance level $(\mathrm{z}=-3.98)$. It indicates the negative link with the level of underpricing. Notwithstanding, null hypothesis 7 is rejected. There is a significant relationship between market capitalization and level of underpricing at $5 \%$ significance level $(z=2.04)$. This indicates that market capitalization has a positive effect on the level of underpricing. Therefore, null hypothesis 8 is declined. Significant relationship between subscription and the level of underpricing at $5 \%$ significance level (6.00). It reveals the positive relation with the level of underpricing. Nevertheless, Null hypothesis 9 is rejected. There is a significant difference between book build mechanism and level of underpricing@5\% significance level
Table 3.

Result of multiple regression analysis.

\begin{tabular}{|c|c|c|c|c|}
\hline Variable & Coefficient & Std. Error & z-Statistic & Prob. \\
\hline $\mathrm{C}$ & -0.911365 & 2.01968 & -0.45124 & 0.6521 \\
\hline A0 & -0.553498 & 0.48234 & -1.14751 & 0.2521 \\
\hline A11 & 0.741755 & 0.43712 & 1.99689 & 0.0908 \\
\hline A 10 & -0.173135 & 0.36700 & -0.47174 & 0.6375 \\
\hline A1 & -0.478039 & 0.99483 & -0.48051 & 0.6312 \\
\hline $\mathrm{A} 3$ & -0.353389 & 0.57702 & -0.61243 & 0.5407 \\
\hline A4 & -0.174027 & 0.46982 & -0.37040 & 0.7113 \\
\hline A5 & -0.565943 & 0.3752 & -1.50829 & 0.1325 \\
\hline A6 & -0.633422 & 0.35223 & -1.99831 & 0.0731 \\
\hline A7 & -0.225688 & 0.34596 & -0.65234 & 0.5147 \\
\hline A9 & -0.875579 & 0.45515 & -1.99370 & 0.0554 \\
\hline INDIANPROM & 0.001107 & 0.00589 & 0.18779 & 0.8512 \\
\hline NONPROMINST & 0.004381 & 0.00808 & 0.54198 & 0.5882 \\
\hline NONPRMNOINS & 0.005096 & 0.00649 & 0.78459 & 0.4333 \\
\hline LGNOOFSHARE & 0.158054 & 0.09474 & 1.99823 & 0.0963 \\
\hline LOGAGE & -0.065194 & 0.09218 & -0.70754 & 0.4800 \\
\hline LOGISSUESIZE & -0.689532 & 0.17302 & -3.98553 & 0.0001 \\
\hline LOGMKTCAP & 0.197068 & 0.11279 & 2.04716 & 0.0816 \\
\hline LOGSUBSC & 0.390509 & 0.06500 & 6.00696 & 0.0000 \\
\hline BB & 0.417627 & 0.24945 & 2.67416 & 0.0952 \\
\hline PVT & 0.111877 & 0.27706 & 0.40379 & 0.6867 \\
\hline A2 & -0.473831 & 0.764036 & -0.62069 & 0.5356 \\
\hline LOG_DIFF IN A & 0.681698 & 0.351824 & 1.99709 & 0.0536 \\
\hline R-squared & 0.440426 & \multicolumn{2}{|c|}{ Mean dependent v } & 3.020999 \\
\hline $\begin{array}{l}\text { Adjusted } \\
\text { R-squared }\end{array}$ & 0.391403 & \multicolumn{2}{|c|}{ S.D. dependent var } & 1.484142 \\
\hline S.E. of regression & 1.249324 & \multicolumn{2}{|c|}{ Akaike info criterion } & 3.352451 \\
\hline Sum squared resid & 461.9999 & \multicolumn{2}{|c|}{ Schwarz criterion } & 3.623923 \\
\hline Log likelihood & -511.7160 & \multicolumn{2}{|c|}{ Hannan-Quinn criter. } & 3.460867 \\
\hline F-statistic & 6.944287 & \multicolumn{2}{|c|}{ Durbin-Watson stat } & 1.589472 \\
\hline Prob (F-statistic) & 0.000000 & & & \\
\hline
\end{tabular}

$(z=-2.67)$. This indicates that book building has a positive effect on the level of underpricing. Nonetheless, null hypothesis 10 is rejected. No significant link of private issuing firms with the level of underpricing at $5 \%$ significance level $(z=0.40)$. However, null hypothesis 11 is accepted. There is a positive association between offer timing and level of underpricing at $5 \%$ significance level $(\mathrm{z}=1.99)$. Nevertheless, null hypothesis 12 is turned down. 
Table 4.

Results of null hypothesis @ 5\% significance level ( $\mathrm{z}= \pm 1.96)$.

\begin{tabular}{|c|c|c|c|c|}
\hline S. No. & Variable & z-Stat & $\begin{array}{c}\text { Null } \\
\text { hypothesis H0 }\end{array}$ & $\begin{array}{l}\text { Relation with } \\
\text { underpricing }\end{array}$ \\
\hline 1 & LOGISSUESIZE & -3.98 & Rejected & Negative \\
\hline 2 & LOGINDP & 0.18 & Accepted & No relation \\
\hline 3 & LOGINDNONP & 0.54 & Accepted & No relation \\
\hline 4 & LOGNONINSTNONP & 0.78 & Accepted & No relation \\
\hline 5 & $\begin{array}{c}\text { LOG NO OF } \\
\text { SHARES }\end{array}$ & 1.99 & Rejected & Positive \\
\hline 6 & LOGAGE & -0.70 & Accepted & No relation \\
\hline 7 & LOGMKTCAP & 2.04 & Rejected & Positive \\
\hline 8 & $\mathrm{BB}$ & 2.67 & Rejected & Positive \\
\hline 9 & SUBSCRIPTION & 6.00 & Rejected & Positive \\
\hline 10 & PRIVATE FIRM'S & 0.40 & Accepted & No relation \\
\hline 11 & OFFER TIMING & 1.99 & Rejected & Positive \\
\hline 12 & Y2000 & -1.14 & Accepted & No relation \\
\hline 13 & Y2001 & -0.48 & Accepted & No relation \\
\hline 14 & Y2002 & -0.62 & Accepted & No relation \\
\hline 15 & Y2003 & -0.61 & Accepted & No relation \\
\hline 16 & Y2004 & -0.37 & Accepted & No relation \\
\hline 17 & Y2005 & -1.50 & Accepted & No relation \\
\hline 18 & Y2006 & -1.99 & Rejected & Negative \\
\hline 19 & Y2007 & -0.65 & Accepted & No relation \\
\hline 20 & Y2009 & -1.99 & Rejected & Negative \\
\hline 21 & Y2010 & -0.48 & Accepted & No relation \\
\hline 22 & Y2011 & 1.99 & Rejected & Positive \\
\hline
\end{tabular}

\section{Conclusion}

Taking into account all firms which have gone public on the official market of the Stock Exchange of Bombay for the period 1999 until 2011, this study examines the evidence on the shortrun under-pricing of IPOs. In particular, an average underpricing level within the range $50 \%$ is found based on the first day. Using a regression approach, the degree of underpricing is explained by the ex-ante uncertainty hypothesis and the ownership structure hypothesis. However, there is limited support for the signaling hypothesis. In particular, the results show that the ex-ante information and has a significant positive impact on the initial returns while the ownership structure has no relevant negative effect on short-run underpricing. Conversely, the results show that there is no statistically significant relationship with other explanatory factors such as return on firm's age, and IPO years, ownership structure and the level of underpricing.

The results obtained from this study (see Table 4) show that fresh issues on the BSE are subject to underpricing, consistent with developed and other emerging markets. In this respect, prospective investors should pursue the strategy of buying the new issues at the offer and selling them immediately on the initial day of trading. Notwithstanding, the study also reveals that investors should not hold new issues very long as the highest component of the initial returns is found on the first day of trading and that the average original returns turn negative on the fourth day of trading.

\section{REFERENCES}

Allen, F., \& Faulhaber, G. (1989). Signaling by under pricing in the IPO market. Journal of Financial Economics, 23, 303-323. doi:10.1016/0304-405X(89)90060-3

Baker, M., \& Wurgler, J. (2007). Investor sentiment in the stock market. Journal of Economic Perspectives, 21, 129-151. doi:10.1257/jep.21.2.129

Baron, D. P. (1982). A model of the demand for investment banking advising and distribution services for new issues. The Journal of Finance, 37, 955-976. doi:10.1111/j.1540-6261.1982.tb03591.x

Barry, C. B., \& Brown, S. (1985). Differential information and security market equilibrium. Journal of Financial Quantitative Analysis, 20, 407-422. doi: 10.2307/2330758

Bansal, R., \& Khanna, A. (2012). Pricing mechanism and explaining underpricing of IPOs, evidence from Bombay stock exchange India. International Journal of Research in Finance and Marketing, 2, 205216.

Bansal R., \& Khanna, R. (2012). Post Indian stock market's crisis and its impact on IPOs underpricing: Evidence from 2008-2011. Asian Journal of Management Research, 3, 1-11.

Bansal R., \& Khanna, R. (2012). IPOs underpricing and money "left on the table" in Indian market. International Journal of Research in Management, Economics and Commerce, 2, 106-120.

Bansal R., \& Khanna, R. (2012). Share holding's pattern and its impact on IPO Underpricing: After Indian stock market crisis in 2008. Asian Journal of Research in Business, Economics and Management, 2, 159-174.

Bansal R., \& Khanna, R. (2012). Does ownership structure affecting IPO underpricing: A case of Indian stock market. International Journal of Business Economics and Management Research, 3, 39-51.

Bansal R., \& Khanna, R. (2012). IPO underpricing cloud or rain: Event commencing from Bombay stock exchange. International Journal of Management and Behavioural Science, 1, 154-179.

Bansal R., \& Khanna, R. (2012). Analysis of IPO underpricing: Evidence from Bombay stock Exchange. International Journal of Research in Commerce, It \& Management, 2, 1-6.

Benveniste, L. M., \& Spindt, P. A. (1989). How investment bankers determine the offer price and allocation of new issues. Journal of Financial Economics, 24, 343-361. doi:10.1016/0304-405X(89)90051-2

Dolvin, S. D., \& Jordan, B. D. (2008). Underpricing, overhang, and the cost of going public to pre-exiting shareholders. Journal of Business Finance and Accounting, 35, 434-458. doi:10.1111/j.1468-5957.2008.02087.x

Grinblatt, M., \& Hwang, C. Y. (1989). Signaling and the pricing of new issues. Journal of Finance, 44, 393-420

Loughran, T., \& Ritter, J. R. (1994). Initial pubic offerings: International insights. Pacific Basin Finance Journal, 2, 165-199. doi:10.1016/0927-538X(94)90016-7

Leite, T. (2007). Adverse selection, public information, and underpricing in IPOs. Journal of Corporate Finance, 13, 813-903. doi:10.1016/j.jcorpfin.2007.04.010

McDonald, J. G., \& Fisher, A. K. (1972). New issues stock price behavior. Journal of Finance, 27, 97-102. doi:10.1111/j.1540-6261.1972.tb00624.x

Megginson, W. L., \& Weiss, K. A. (1991). Venture capitalist certification in initial public offerings. Journal of Finance, 46, 879-903. doi:10.1111/j.1540-6261.1991.tb03770.x

Muscarella, C. J., \& Vetsuypens, M. R. (1989). A simple test of Baron's model of IPO underpricing. Journal of Financial Economics, 24, 125-135. doi:10.1016/0304-405X(89)90074-3 


\section{R. BANSAL, A. KHANNA}

Rock, K. (1986). Why new issues are underpriced? Journal of Financial Economics, 15, 187-212. doi:10.1016/0304-405X(86)90054-1

Ritter, J. R. (1991). The long run performance of initial public offerings. The Journal of Finance, 46, 3-27.
Welch, I. (1989). Seasoned offerings, imitation costs and the under pricing of initial public offerings. Journal of Finance, 47, 695-732. doi:10.1111/j.1540-6261.1992.tb04406.x 